\title{
Seroprevalence of Hepatitis-A Virus Among Child and Adult Age Groups Admitted to a Training and Research Hospital
}

\author{
Bir Eğitim ve Araștırma Hastanesine Bașvuran Çocuk ve Erișkin Yaș Gruplarında Hepatit A Virüs \\ Seroprevalansı
}

\author{
Mehmet PARLAK1, Ayşe GÜVEN2, Begüm Nalça ERDIN2, Yasemin BAYRAM1 \\ 1 Yüzüncü Yıl University Faculty of Medicine, Department of Medical Microbiology, Van, Turkey \\ 2Van Training and Research Hospital, Microbiology Laboratory, Van, Turkey
}

\section{ABSTRACT}

Objective: Owing to its transmission via fecal-oral route, prevalence of hepatitis A virus (HAV) is naturally in line with economic development of a region. The present study aimed to determine the seroprevalence of hepatitis $A$ among pediatric and adult age groups admitted to a training and research hospital.

Materials and Methods: Presence of anti-HAV IgM and IgG antibodies was investigated in serum samples, which were transferred to our laboratory between June 2012 and July 2013 with the pre-diagnosis of HAV infection, and positive samples were retrospectively analyzed according to the age groups. Anti-HAV IgM and IgG antibodies were analyzed by the chemiluminescent microparticle immunoassay (CMIA) and electrochemiluminescence immunoassay (ECLIA) using Cobas ${ }^{\circledR} 4000$ e411 (Roche, Germany) and Architect i2000SR (Abbott Diagnostics, Germany) analyzers.

Results: Results of 6697 patients were analyzed in terms of the presence of anti-HAV antibodies. Anti-HAV IgM and anti-HAV IgG positivity rates were $2.9 \%$ and $89.9 \%$, respectively, for all age groups. It was observed that anti-HAV IgM positivity was increased after the age of 1 year, reached to the maximum level at the age of 6-7 years, and regressed to below $1 \%$ after the age of 14 years. Whilst anti-HAV IgG positivity was determined to be $34 \%$ at the age of $0-1$ years, it regressed to $27 \%$ at the next range of age and then increased with age.

Conclusion: The present study found high anti-HAV IgM positivity particularly in pediatric age group. Necessary public health measures should be precisely carried out due to the reasons like crowded family life and higher number of school-age children.

Key Words: Hepatitis A virus, IgM, IgG

Conflict of interest: The authors reported no conflict of interest related to this article.
ÖZET

Amaç: Hepatit A virüs prevalansı, fekal-oral yolla bulaşması nedeni ile doğal olarak bölgenin ekonomik gelişimi ile paralellik göstermektedir. Çalışmada, bir eğitim ve araştırma hastanesine başvuran çocuk ve erişkin yaş grubundaki hastalarda Hepatit A seroprevalansının belirlenmesi amaçlanmıştır.

Gereç ve Yöntemler: Haziran 2012-Temmuz 2013 tarihleri arasında Hepatit Aön tanısıyla laboratuvarımıza gönderilen serum örneklerinde anti-HAV IgM ve IgG varlığı araştırılarak pozitif olduğu belirlenen örnekler yaş gruplarına göre, retrospektif olarak incelenmiştir. AntiHAV IgM ve IgG antikorları Cobas ${ }^{\circledR} 4000$ e411 (Roche, Almanya) ve Architect i2000SR (Abbott Diagnostics, Almanya) analizatörleri kullanılarak Kemilüminesan Mikropartikül Immunoassay (CMIA) ve Elektrokemilüminesan Immunoassay (ECLIA) yöntemle araştırılmıştır.

Bulgular: Çalışma süresince toplam olarak 6697 hastanın sonuçları HAV antikorları açısından araştırımıştır. Tüm yaş grupları için AntiHAV IgM ve anti-HAV IgG saptama oranı sırasıyla \%2,9 ve \%89,9 olarak bulunmuştur. IgM'nin, bir yaş sonrası artış gösterip bu artışın 6-7 yaşlarda maksimum seviyeye yükseldiği ve 14 yaşından sonra \%1'lerin altına gerilediği görülmüştür. lgG'nin ise 0-1 yaşta \%34 oranında saptanırken bir sonraki yaş aralığında \%27'ye gerilediği ve daha sonra yaş artışına paralel olarak artış gösterdiği tespit edilmiştir. Sonuç: Çalışmamızda özellikle çocuk yaş grubunda anti HAV IgM pozitifliği yüksek oranda bulunmuştur. Kalabalık aile yaşamı, okul çağında bulunan çocuk sayısının fazlalığı gibi nedenlerle gerekli halk sağlığı tedbirlerinin titizlikle yürütülmesi gerekmektedir.

Anahtar Kelimeler: Hepatit A virüs, IgM, lgG

Çıkar çatışması: Yazarlar bu makale ile ilgili olarak herhangi bir çıkar çatışması bildirmemişlerdir. 


\section{Introduction}

Hepatitis A virus (HAV) is a member of the Hepatovirus genus of Picornaviridae family. It is a single-stranded RNA virus with a nonenveloped icosahedral structure. HAV has only one serotype. It has some properties of enteroviruses such as stability and resistance to inactivation at low pH levels and at a temperature of $-20^{\circ} \mathrm{C}(1,2)$.

Acute hepatitis A infection shows different clinical courses ranging from asymptomatic infection to fulminant disease. Diagnosis of hepatitis $A$ is based on demonstration of specific antibodies against HAV using ELISA method $(2,3)$.

Since HAV is transmitted by the fecal-oral route, its prevalence is naturally in line with economic development of the region. Although its prevalence has been decreased in developed countries along with improved hygiene conditions, it leads to substantial rates of morbidity and economic loss in developing countries. In Turkey, the prevalence of anti-HAV antibody positivity in adult age-group is reported between $89 \%$ and $100 \%(3,4)$. The HAV seroprevalence rate in pediatric patients under 10 years of age is lower than $40 \%$. The HAV seroprevalence increases depending on the age $(5,6)$.

The present study aimed to investigate the seroprevalence of hepatitis A among pediatric and adult age groups admitted to our hospital, which serves as a training and research hospital.

\section{Materials and Methods}

The presence of anti-HAV IgM and lgG antibodies was explored in serum samples sent to our laboratory with a prediagnosis of hepatitis A between June 2012 and July 2013, and positive samples were retrospectively investigated according to age groups. A total of 6697 patients were included in the study, 3537 of them were investigated for anti-HAV IgM and 5363 were investigated for anti-HAV IgG. Only one of anti-HAV IgM and lgG tests were studied in 4492 patients. Both anti-HAV IgM and lgG were tested in a total of 2205 patients. Pediatric patients were divided into seven groups (0-1, 2-3, 4-5, 6-7, 8-9, 10-11, 12-13) and adult patients were divided into three groups $(14-19,20-29,>30)$.

Blood samples obtained for anti-HAV IgM and IgG antibody screening were centrifuged at $10.000 \mathrm{rpm}$ for $15 \mathrm{~min}$ and then examined by the chemiluminescent microparticle immunoassay (CMIA) and electrochemiluminescence immunoassay (ECLIA) within 2 hours at the latest using Cobas ${ }^{\circledR} 4000$ e411 (Roche, Germany) and Architect i2000SR (Abbott Diagnostics, Germany) analyzers. The statistical difference between the age groups was analyzed by comparison of ratios using $Z$ test, and a $p$ value of $<0.05$ was considered significant.

\section{Results}

Over the course of the study period, the results of 6697 patients were examined in terms of anti-HAV antibodies. Anti-HAV IgM antibody was evaluated in 3537 patients and positivity rate was found to be $2.9 \%$ in all age groups, whereas anti-HAV IgG antibody was analyzed in 5363 patients and the positivity rate was found to be $89.9 \%$ in all age groups. A total of 207 patients were found negative in both anti-HAV IgM and IgG test results. It was observed that $\lg \mathrm{M}$ antibody increased after the age of 1 year and peaked at the age of 6-7 years; it gradually decreased thereafter and regressed below $1 \%$ after the age of 14 years. While the positivity rate of IgG antibody was about 34\% at the age of 0-1 year, it regressed to $27 \%$ in the next age group and increased thereafter in line with age. Rates of anti-HAV IgM and IgG antibody positivity are presented in Table 1 and Figure 1.

\section{Discussion}

HAV is frequently encountered from early childhood in underdeveloped and developing countries and maintains its importance as an important public health problem. Particularly, small children with asymptomatic infection are responsible for intra-familial transmission. Transmission is more common in the incubation period when the individual is still asymptomatic. Environments with crowded living conditions such as hospitals, schools, nurseries, preschools, and continuing care centers are important places for the development of outbreaks (7).

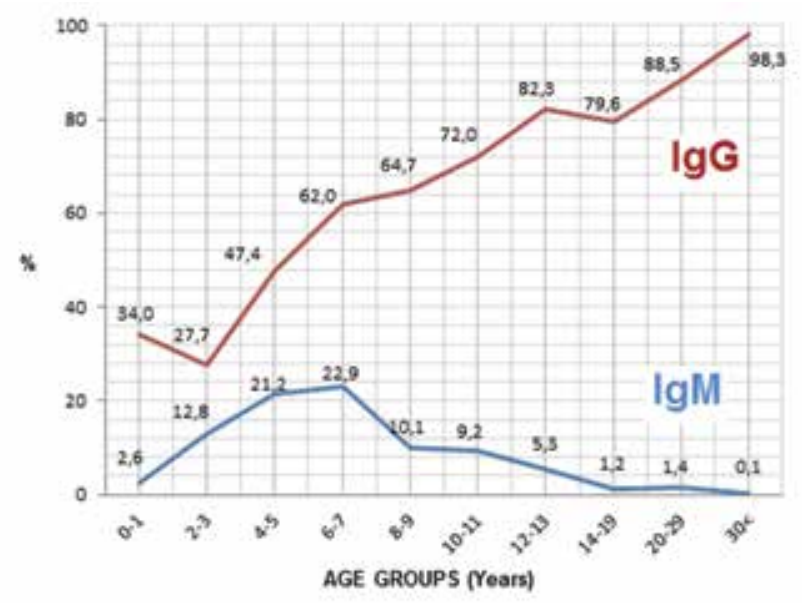

Figure 1. Positivity rates of anti-HAV IgM and $\lg G$ antibody

\begin{tabular}{|c|c|c|c|c|c|c|}
\hline \multirow{2}{*}{$\begin{array}{l}\text { Age Groups } \\
\text { (years) }\end{array}$} & \multicolumn{3}{|c|}{$\lg M$} & \multicolumn{3}{|c|}{$\lg G$} \\
\hline & Positive & $\%$ & n & Positive & $\%$ & $\mathrm{n}$ \\
\hline \multicolumn{7}{|c|}{ Pediatric age group } \\
\hline $0-1$ & 3 & 2.6 & 115 & 16 & 34.0 & 47 \\
\hline $2-3$ & 12 & 12.8 & 94 & 13 & 27.7 & 47 \\
\hline $4-5$ & 24 & 21.2 & 113 & 27 & 47.4 & 57 \\
\hline $6-7$ & 25 & 22.9 & 109 & 31 & 62.0 & 50 \\
\hline $8-9$ & 8 & 10.1 & 79 & 33 & 64.7 & 51 \\
\hline $10-11$ & 8 & 9.2 & 87 & 54 & 72.0 & 75 \\
\hline $12-13$ & 5 & 5.3 & 95 & 65 & 82.3 & 79 \\
\hline Total & 85 & 12.3 & 692 & 239 & 58.9 & 406 \\
\hline \multicolumn{7}{|c|}{ Adult age group } \\
\hline $14-19$ & 4 & 1.2 & 347 & 475 & 79.6 & 597 \\
\hline $20-29$ & 12 & 1.4 & 867 & 1586 & 88.5 & 1793 \\
\hline $30<$ & 2 & 0.1 & 1631 & 2523 & 98.3 & 2567 \\
\hline Total & 18 & 0.6 & 2845 & 4584 & 92.5 & 4957 \\
\hline Total & 103 & 2.9 & 3537 & 4823 & 89.9 & 5363 \\
\hline
\end{tabular}


While the prevalence of anti-HAV antibody is low in Japan, Australia, New Zealand, Canada, America and most of the European countries, many Latin American, Asian and Middle Eastern countries have high prevalence, although average seroprevalence rates are declining (8). The world is divided into three endemicity regions as high, moderate and low, according to the detection rate of HAV. Turkey is in the moderate endemicity region with a seroprevalence of $40-70 \%$ in 10-year age group and $90 \%$ over the age of 15 years. Some epidemiological studies in Turkey have reported that seropositivity is declining $(4,5)$.

Demirpençe et al. (9) reported anti-HAV IgG antibody positivity to be $93.9 \%$ in outpatients in Batman; whereas, Turhan et al. (10) reported anti-HAV IgG antibody positivity rate of $81.1 \%$ in Hatay and expressed that positivity increased with age. Kurt et al. (11) found the overall anti-HAV IgG antibody positivity to be $79.3 \%$ in healthy individuals in Ankara and observed that positivity was over $96 \%$ in individuals older than 25 years of age. Özen and colleagues (12) reported IgG antibody positivity rate of $25.9 \%$ within the age range of 2-16 years in Malatya province and determined that the rate of positivity was higher among school children. Similar with this study, Arvas et al. (13) found the rate of IgM antibody to be $18.1 \%$ in children of $0-18$-year-age group and reported that the highest rates were detected in 6-12-year-age group, which is the primary school-age group. Kalem et al. (14) carried out a study in Konya province and reported the rate of anti-HAV IgM antibody to be $2.89 \%$ and that of anti-HAV IgG antibody to be $77 \%$. They found that anti-HAV IgM antibody positivity was significantly higher in patients living in the periphery of Konya as compared to those living in the city center. Karslıgil and colleagues (15) found antiHAV IgM and IgG antibody positivity rate of $19.4 \%$ and $74.6 \%$, respectively in Gaziantep. In addition, they demonstrated that anti-HAV IgM antibody positivity rate was the highest between the ages of 5 and 14 years. Tekay (16) reported anti-HAV IgM and IgG antibody positivity to be $5 \%$ and $68 \%$ in Hakkari, which is close to our province. This lower anti-HAV IgM antibody rate as compared to the other studies was attributed to the higher socioeconomic level of the individuals that were able to go to hospital.

In the present study, anti HAV IgM and IgG antibody positivity rates were found to be $2.9 \%$ and $89.9 \%$, respectively in all age groups. It was observed that IgM antibody positivity was higher within the age range of 2-11 years, with the highest rates found in the age range of 6-7 years. This was attributed to the crowded family life and high number of school-age children. It was observed that IgG antibody positivity increases in line with age. Moreover, it was concluded that higher rates observed in 0-1-year-age group as compared to 2-3-year-age group might have resulted from the antibodies transferred from the mother. Considering all age groups, it appears that the results of the present study are consistent with the above mentioned literature information.

\section{Conclusions}

The present study found high anti HAV IgM antibody positivity rates, particularly in the pediatric age group. Considering that the prevalence of HAV shows parallelism with age, socio-economic status, crowded family life, higher number of school-age children and the level of development and decreases with the increase in socio-economic level, necessary public health measures must be carried out meticulously.

\section{References}

1. Ryan KJ. Hepatitis viruses. In: Ray CG (eds.), Sherris Medical Microbiology. 5 th Ed. United States of America: The McGrawHill Co; 2010. p.225-237.

2. Murray PR. Medical Microbiology. In: Rosenthal KS, Pfaller MA (eds.), 5th ed. Elsevier Mosby, Philadelphia: Pensilvania; 2005. p.675-685.

3. Yoldaş Ö, Bulut $A$, Altındiş M. Hepatit A enfeksiyonlarına güncel yaklaşım. Viral Hepatit Derg. 2012; 18: 81-86.

4. Badur S. Viral Hepatitler (HAV, HBV, HDV). Içinde: Ustaçelebi S, Abacıoğlu H, Badur S(eds.) Moleküler, Klinik ve Tanısal Viroloji, Güneş Kitabevi, Ankara; 2004. p.175-202.

5. Türker K, Balcı E, Batı S, Hasçuhadar M, Savaş E. Ülkemizde Hepatit A enfeksiyonunun değişen epidemiyolojisi. Türk Mikrobiyol Cem Derg. 2011; 41:143-148.

6. Uluğ M, Yaman Y, Yapıcı F, Uluğ NC. Çocuk yaş grubu akut viral hepatit A olguları ve komplikasyonlarının irdelenmesi. Çocuk Enf Derg. 2010; 4:65-70.

7. Willke Topçu A, Söyletir G, Doğanay M. Enfeksiyon Hastalıkları ve Mikrobiyolojisi. Nobel Tıp Kitabevleri, 3. Baskı, Istanbul; 2008. p.1871-1882.

8. Jacobsen $\mathrm{KH}$, Koopman JS. Declining hepatitis A seroprevalence: a global review and analysis. Epidemiol Infect. 2004; 132:1005-1022.

9. Demirpence Ö, Tezcan SI, Değirmen E, Mert D, Gumuş A, Celen MK. Batman devlet hastanesine başvuran kişilerde Hepatit ve HIV serolojisinin sonuçları. Viral Hepatit Derg. 2012; 18:6-10.

10. Turhan E, Çetin M. Mustafa Kemal Üniversitesi Tıp Fakültesi Eğitim, Araştırma ve Uygulama Hastanesine başvuran hastalarda Hepatit A seroprevalansı. Viral Hepatit Derg. 2007; 12:30-34.

11. Kurt H, Battal I, Memikoğlu O, Yeşilkaya A, Tekeli E. Ankara Bölgesinde sağlıklı bireylerde HAV, HBV, HCV seroprevalansının yaş ve cinsiyete göre dağılımı. Viral Hepatit Derg. 2003; 8: 88-96.

12. Özen M, Yoloğlu S, Işık $Y$, Tekerekoğlu MS. Turgut Özal Tıp Merkezi'ne başvuran 2-16 yaş grubundaki çocuklarda anti-HAV IgG seropozitifliği. Türk Pediatri Arş. 2006; 41:36-40.

13. Arvas G, Kaya B, Berktaş M. Iğdır Devlet Hastanesine Başvuran 0-18 Yaș Grubu Çocuklarda Akut Hepatit A Seroprevalansı. J Pediatr Inf. 2011; 5:129-131.

14. Kalem F, Erayman E, Yüksekkaya Ş, Kara F. Konya Illinde Hepatit A seroepidemiyolojisi. Viral Hepatit Derg. 2013; 19:19-22.

15. Karslıgil T, Ekşi F, Balcı I, Belgin R. Bölgemizde A ve E hepatitlerinin seroprevalansı. Viral Hepatit Derg. 2003; 8:155-1599.

16. Tekay F. Hakkâri Devlet Hastanesine Başvuran 0-14 yaş grubu çocuklarda Hepatit A sıklığı. Dicle Tıp Derg. 2006; 33:245-247. 